\title{
Royal Women and Gendered Communication: Female Voices in Carolingian Diplomas*
}

\author{
Roberta Cimino
}

The "Annals of St-Bertin", a ninth-century annalistic text written by authors connected to the West Frankish court, report a tale about Boso of Vienne and his wife. In 879, Boso, a Frankish aristocrat who had worked for several years as chancellor of King Charles the Bald (840-877), took advantage of the chaos within the Carolingian dynasty and was elected king in Provence. ${ }^{1}$ The Carolingians reacted with violence: after a couple of years Boso was defeated and had to give up his royal title. According to the "Annals", one of the driving forces behind Boso was his wife Ermengard. She was the daughter of Emperor Louis II (855-875) and was not satisfied with being just the wife of a nobleman: "She declared that, as the daughter of the emperor of Italy, and the one time fiancée of the emperor of Greece, she had no wish to go on living unless she could make her husband a king."

* For the series Monumenta Germaniae Historica I will use the standard abbreviation MGH, as well as SS for the collection Scriptores and DD for Diplomata.

I am grateful to Simon MacLean, Edward Roberts, Xenia von Tippelskirch and the reviewers of "L'Homme. Z. F. G." for their helpful advice, comments and criticism. Many thanks also to my colleagues on the project "Political Language in the Middle Ages: Semantical Approaches" at GoetheUniversität Frankfurt am Main.

I For a summary of Boso's revolt cf. Simon MacLean, The Carolingian Response to the Revolt of Boso, 879-887, in: Early Medieval Europe 10 (2001), 21-48, 21-24 with relevant bibliography; Stuart Airlie, The Nearly Men: Boso of Vienne and Arnulf of Bavaria, in: Anne Duggan ed., Nobles and Nobility in Medieval Europe. Concepts, Origins, Transformations, Woodbridge 2000, 25-41, esp. 34-36.

2 Félix Grat, Jeanne Vielliard and Suzanne Clémencet eds., Annales de St-Bertin, Paris 1964, 239. I am using the English translation by Janet Nelson, The Annals of St-Bertin, Manchester 1991, 219. On Ermengard cf. François Bougard, Ermengarda, Dizionario Biografico degli Italiani 43, Roma 1993, 214-215. 
This is just one passage among many others in early medieval texts which focus on female voices. The persuasive words of women were considered a powerful resource which could cause problems when left uncontrolled, as was the case for Boso and his revolt. ${ }^{3}$ Because of their intimacy with their husbands, wives could exercise a dangerous influence on them. However, their impact could also be positive: women's words could be redeeming, they could convert and solve conflicts. ${ }^{4}$ Nevertheless, early medieval authors insisted on the fact that female voices should be regulated by a male authority, because women lacked sufficient rationality to control their words. The lack of such regulation could lead to disaster.

Female persuasiveness was considered dangerous because it could affect a range of domains: family relations, spirituality and political affairs. Particularly with regard to kings, the incapability of a husband to supervise his wife, and the danger of being negatively influenced by her, could have serious political repercussions. How is a ruler too weak to control his own wife capable of ruling a kingdom? This point is effectively expressed by the ninth-century writer Sedulius Scotus in his treatise "On Christian Rulers". Sedulius states that one of the king's priorities must be to rule his own family and household - and he warns kings against the power of female words, both positive and negative: "Just as by the persuasion of an evil wife pernicious dangers are begotten, so by the counsel of a prudent wife many benefits are produced." 5

Research on early medieval kinship has highlighted the importance of maternal descent in early medieval aristocratic groups, and the significance of women in shaping the identity of their families. ${ }^{6}$ This is also true for women of the royal family, who had the opportunity to play a significant part in royal politics. ${ }^{7}$ Wives, concubines, mothers and daughters of the ruler often lived at court. Due to sexual intimacy - in the case of royal wives and concubines - and familial bonds - in the case of mothers, daughters

3 Cf. Sharon A. Farmer, Persuasive Voices: Clerical Images of Medieval Wives, in: Speculum, 61 (1986), 517-543.

4 Cf. Janet Nelson, Queens as Converters of Kings in the Earlier Middle Ages, in: Cristina La Rocca ed., Agire da donna. Modelli e pratiche di rappresentazione, Turnhout 2007, 95-108; Janet Nelson, Women and the Word in the Earlier Middle Ages, in: Diana Sheils and William Wood eds., Women in the Church, London 1990, 53-78.

5 Sedulius Scotus, Liber de rectoribus christianis, in: Siegmund Hellmann ed., Sedulius Scotus, München 1906, chap. 5, 34-37; English translation by Paul Dutton, Carolingian Civilization. A Reader, Peterborough 1993, 410.

6 For some useful observations and relevant bibliography on this topic cf. Pauline Stafford, La mutation familiale: A Suitable Case for Caution, in: Joyce Hill and Mary Swan eds., The Community, the Family and the Saint. Patterns of Power in Early Medieval Europe, Turnhout 1998, 103-125, 102108. On the evolution of family structures in the Frankish world and its repercussions for the status of noble and royal women cf. Régine Le Jan, Famille et pouvoir dans le monde franc (VIIe-Xe siècle), Paris 1995, 263-332.

7 Cf. Janet Nelson, Gendering Courts in the Early Medieval West, in: Leslie Brubaker and Julia Smith eds., Gender in the Early Medieval World: East and West, 300-900, Cambridge 2004, 185-197, esp. 195. 
and sisters - they enjoyed a unique proximity to the king. This allowed them to develop influence and room for manoeuvre within the political community of the court. ${ }^{8}$ Queens, in particular, played a crucial role in royal politics. In the course of the ninth century, Carolingian intellectuals paid increasing attention to marriage and to the moral role of wives: consequently, queenly activities also became the object of growing scrutiny and discussion. ${ }^{9}$ These activities included administering the court, taking care of the spiritual needs of the family, being involved in the patronage of religious institutions, and, ultimately, acting as political advisors to the king.

Narrative texts frequently describe how arrogant and ambitious queens caused problems and had a negative impact on the king's decisions, as in the case described above. On the other hand, queens often had a positive role: they could act as intercessors on behalf of friends and family members and were asked to intervene in a range of matters. Although narrative and epistolary texts show the influence queens often held at court, they rarely contain descriptions of women who addressed the king with their requests. The only sources that frequently portray women talking to a ruler in a public context are royal charters, documents through which kings granted privileges, rights and properties to individuals and religious institutions. The wealth of information that we can obtain from these sources is impressive. However, Carolingian diplomas have only been marginally studied in relation to gender dynamics and female representation. ${ }^{10}$ Writing and issuing a royal charter was a highly formalised and politically charged event, as through these texts rulers established political bonds and exercised their authority. ${ }^{11}$ Thus the way in which women were portrayed in these documents is highly significant. When a woman was mentioned in a charter - as grantor, petitioner or intercessor - she became part of the narrative of the document and therefore of its message. The aim of this article is to look at instances of women of the Carolingian dynasty speaking in diplomas. ${ }^{12}$ Women asking, interceding or making decisions in charters illuminate the multiple functions of female words and the importance of gender discourse in royal politics. The representation of women tells us about the way in which the men who

8 Cf. Pauline Stafford, Queens, Concubines and Dowagers: The King's Wife in the Early Middle Ages, London 1983, 93-114; Janet Nelson, Women at the Court of Charlemagne: a Case of a Monstrous Regiment?, in: John Carmi Parsons ed., Medieval Queenship, Stroud 1994, 43-61, esp. 59-61; Martina Hartmann, Die Königin im frühen Mittelalter, Stuttgart 2009, 138-162.

9 Cf. Julia Smith, Gender and Ideology in the Early Middle Ages, in: Robert N. Swanson ed., Gender and Christian Religion. Studies in Church History, 34 (1998), 51-73.

IO For a discussion on the study of gender in early medieval texts cf. Julia Smith, Introduction: Gendering the Early Medieval World, in: Brubaker/Smith, Gender, see note 7, 1-19.

II The literature on early medieval documentary evidence is extensive. For a recent discussion on the historiography and methodology of the study of Carolingian royal charters cf. Geoffrey Koziol, The Politics of Memory and Identity in Carolingian Royal Diplomas: The West Frankish Kingdom (840987), Turnhout 2012, esp. chap. 1, 9-62.

I2 On Carolingian women cf. Hartmann, Königin, see note 8, 87-137, esp. 87-89 for lists of the names and chronologies of twenty-four wives, twelve concubines and forty-six daughters. 
wrote and commissioned these documents employed female agency. Furthermore, this article will show that in some cases women were not necessarily passive in this process, but that their decisions and agendas could influence how they were presented and the function that their voice held. When put into context, charters allow us a glimpse of female activism.

\section{Women and the Language of Carolingian Diplomas}

The composition of royal charters was a complex process. Diplomas were authenticated by the royal chancery, which had at its disposal older models and charters issued by previous rulers to copy and imitate. The recipients of charters, particularly in the case of religious institutions, could also play a significant part in drafting these documents. The final text could therefore be the result of several agencies. Nevertheless, diplomas represented the ruler's agenda and their composition was therefore carefully monitored by the royal entourage. Those mentioned in the document, the way in which they were described and the parts they played - all this was functional to the charter's message. When we look at the role of women in these texts, female gendering is also to be taken into account. Was the language of diplomas gendered? At a first glance, the lexicon used to describe women seems not profoundly different from that used for men. Female agents were always presented through attributes that defined their family relationship with the ruler: as mothers, sisters and daughters (mater/genitrix, soror, filia). This was underlined by the frequent use of adjectives belonging to the semantic field of affection, such as "beloved" and "dear", often to be found in the superlative form (carissima, dilectissima, amantissima). These adjectives emphasise the woman's privileged access to the ruler due to a personal bond. They are by no means gender specific, as they were also often used to describe male agents: for relatives, but also for friends and allies, of the king. However, only women were consistently presented through their personal connections to the ruler. Queens, too, were almost always qualified as wives: the formula coniux nostra is most commonly used in diplomas to accompany the name of the queen. This was often, although not always, followed by an attribute which defined her public role: regina, imperatrix, augusta, consors regni and adiutrix regni are among the most common titles. Some of these titles have been read as particularly significant with regard to Carolingian queens' growing political influence in the course of the ninth century. ${ }^{13}$ However, it is difficult to define a specific meaning of these titles, as there is

I3 For example consors regni/imperii cf. Paolo Delogu, "Consors regni”" un problema carolingio, in: Bullettino dell'Istituto storico Italiano per il Medioevo, 76 (1964), 47-98; Franz-Reiner Erkens, "Sicut Esther regina”. Die westfränkische Königin als consors regni, in: Francia, 20, 1 (1993), 15-38, 23-26. The title was used very frequently in Ottonian diplomas, cf. Amalie Fössel, Die Königin im mittelalterlichen Reich. Herrschaftsausübung, Herrschaftsrechte, Handlungsspielräume, Stuttgart 2000, 56-66. 
no clear pattern in terms of when and in which situations they were used. This vagueness, however, is in accordance with the role queens played in Carolingian Europe. As scholars of early medieval queenship stress, the essence of the queen's role lay in the combination of her domestic and public duties. ${ }^{14}$ It was her capacity to merge the familial sphere - as wife, mother and sexual partner - with her public duties, which made the queen's position so significant. ${ }^{15}$ By combining, and often interchanging, expressions that refer to both these spheres, charters confirm how complex and multilayered the queen's role was.

When royal women voiced a request, they did so either for themselves or as intercessors for a third party. The role of the intercessor was charged with political significance: thanks to their proximity to the king, intercessors provided a third party access to the distant ruler. ${ }^{16}$ In Carolingian courts the queen - as well as other royal women, mainly the king's mother - frequently acted as intercessor, although this frequency varied according to individual cases. The queen often interceded alone, but she could also be part of a group of people, usually being the only woman amongst men. In this instance she was always listed first in the document: her role granted her a predominant position in the narrative of the charter. ${ }^{17}$ Nonetheless, female intercessors and petitioners were not presented in a drastically different way from men: they all plead from a position of inferiority, humbled by the ruler's splendour and virtue. Verbs used to describe the action of requesting often belong to the semantic field of pleading, such as deprecare, petere and exorare. Occasionally, we find verbs which suggest a more 'official' act of speaking, such as 'intervene' (intervenire) and 'to act as a messenger' (ambasciare). ${ }^{18}$

I4 Cf. Stafford, Queens, see note 8. Cf. also Pauline Stafford, Powerful Women in the Early Middle Ages: Queens and Abbesses, in: Peter Linehan and Janet Nelson eds., The Medieval World, Abington 2001, 398-415; John Carmi Parsons, Family, Sex and Power: the Rhythms of Medieval Queenship, in: Parsons, Queenship, see note 8, 1-11.

I5 Cf. Janet Nelson, The Problematic in the Private, review of: Paul Veyne ed., A History of Private Life from Pagan Rome to Byzantium, in: Social History, 15, 3 (1990), 355-364; Pauline Stafford, Sons and Mothers: Family Politics in the Early Middle Ages, in: Derek Baker ed., Medieval Women, Oxford 1978, 79-100.

I6 Cf. Sean Gilsdorf, The Favor of Friends: Intercession and Aristocratic Politics in Carolingian and Ottonian Europe, Leiden 2014, 1-41.

17 Cf. Gilsdorf, Favor, see note 16, 114-124; John Carmi Parsons, The Queen's Intercession in Thirteenth-Century England, in: Jennifer Carpenter and Sally-Beth MacLean eds., Power of the Weak: Studies on Medieval Women, Urbana/Illinois 1995, 147-177, 161. On Ottonian empresses as intercessors cf. Ingrid Baumgärtner, Fürsprache, Rat und Tat, Erinnerung: Kunigundes Aufgaben als Herrscherin, in: Stefanie Dick ed., Kunigunde - consors regni. Vortragreihe zum tausendjährigen Jubiläum der Krönung Kunigundes in Paderborn (1002-2002), München 2004, 47-69; Knut Görich, Mathilde, Edgith, Adelheid. Ottonische Königinnen als Fürsprecherinnen, in: Bernd Schneidmüller and Stefan Weinfurter eds., Ottonische Neuanfänge. Symposion zur Ausstellung "Otto der Große, Magdeburg und Europa", Mainz 2001, 251-291.

I8 Ambasciare was used for Empress Judith, wife of Louis the Pious, in 828 (cf. Elizabeth Ward, Caesar's Wife. The Career of the Empress Judith, in: Peter Godman and Roger Collins eds., Charlemagne's Heir. New Perspectives on the Reign of Louis the Pious, Oxford 1990, 205-227, 220), and in 877 for 


\section{Ermentrud: The Queen as Decision-Maker}

When read in relation to the content of the charter, these titles and verbs can give us an insight into the role assigned to a woman. An example is the verb innotescere ('to be made known'), which was rarely used for women. It was, however, employed twice for Queen Ermentrud, the first wife of Charles the Bald. First, it appears in a donation issued by Charles in 854 for the convent of Chelles. ${ }^{19}$ The charter confirmed an exchange of properties between Ermentrud, who was the rectrix of Chelles, and another religious house, Fossés. Hence, it documented a transaction which had already been autonomously carried out by the queen. According to the narrative of the charter the queen 'informed' (innotuit) the king of her decisions, and he confirmed them. We find the same pattern in a donation issued in 856 for the monastery of Corbie. ${ }^{20}$ This document reports that Ermentrud had given some of the properties she had received from Charles as a dower (per dotis titulum) to Corbie. Therefore the charter portrays Ermentrud as the patron of this religious house and in control of the estates that were the object of the transaction. The dispositions Charles made in his capacity as king are thus described as a ratification of decisions taken by his wife. It is not only the use of the verb that depicts Ermentrud's active involvement, but the whole document. However, the choice of the term innotescere is significant in stressing the message of the charter, because it displays the queen's agency as a crucial element of these transactions. This example shows that individual words can help illuminate the role women played in charters as well as the way in which their activities were presented. In the two diplomas Ermentrud speaks in her capacity of rectrix of religious houses, a task that was often carried out by queens and other women of the royal family. ${ }^{21}$ Furthermore, her role as a monastic patron is combined with her ability to make decisions and communicate them effectively to the king. Although the two grants were issued by Charles, they show the autonomy and agency of the queen: Ermentrud officially carried out a personal sale before this was ratified by the king. The representation of Ermentrud as an influential agent is coherent with the im-

Richildis, second wife of Charles the Bald, cf. Ferdinand Lot and Georges Tessier eds., Recueil des actes de Charles II le Chauve, roi de France (840-877), Paris 1943-1955, n. 433. For discussion on the meaning of these terms cf. Gilsdorf, Favor, see note 16, 15-22.

I9 Cf. Lot/Tessier, Recueil, see note 18, n. 170. On Ermentrud cf. Jane Hyam, Ermentrude and Richildis, in: Janet Nelson and Margaret Gibson eds., Charles the Bald: Court and Kingdom, Aldershot 1990, 153-168, esp. 162-164; Johannes Bernwieser, Ad deprecationem karissimae et amantissimae conjugis nostre Yrmintrudis. Zur Herrschaftspraxis und zum sozialen Netzwerk der Königin Ermentrud († 869), in: Christiane Kunst ed., Matronage: Handlungsstrategien und soziale Netzwerke antiker Herrscherfrauen, Rahden 2013, 145-156.

20 Cf. Lot/Tessier, Recueil, see note 18, n. 189.

2I Cf. Simon MacLean, Queenship, Nunneries and Royal Widowhood in Carolingian Europe, in: Past and Present, 178 (2003), 3-38, 12-20; Cristina La Rocca, Monachesimo femminile e poteri delle regine tra VIII e IX secolo, in: Giovanni Spinelli ed., Il Monachesimo italiano dall'età longobarda all'età ottoniana (VIII-X secolo), Cesena 2006, 119-142, esp. 119-122. 
age conveyed by other sources, as they portray Charles' wife as a powerful queen who seems to have enjoyed a successful partnership with her husband. But her image in the charters can also be read vis-à-vis Charles' relationship with the monasteries. In particular, significant discontent with Charles seems to have developed in Corbie in the mid850 s. $^{22}$ By acknowledging and celebrating his wife's attention towards this institution, Charles may also have intended to improve his relationship with the monastic community.

\section{Queenly Titles: Ansa and Hildegard}

The queen's voice could support, more or less explicitly, the political claims which the charter conveyed. Likewise, queenly titles and attributes can illuminate the circumstances in which they were used. An example of this is Queen Hildegard, who in June 774 granted a donation together with her husband Charlemagne (768-814). Hildegard's representation has a crucial function in this charter. Earlier that year, Charlemagne had conquered the Lombard kingdom, thus annexing a large part of central and northern Italy to his domain. The diploma refers to the estate and castle of Sirmione (on Lake Garda) that Charles, jointly with his wife, assigned to St Martin of Tours. ${ }^{23}$ This is the second charter we know of that portrays Charles as king of the Lombards (“Carolus gratia dei rex Francorum et Longobardorum atque patricius Romanorum”): in so doing, it celebrates his newly acquired power over Italy. ${ }^{24}$ It is also the only royal charter mentioning one of Charlemagne's wives as a co-grantor. The queen is presented as "coniux nostra Hildegardis regina", a formula which highlights her office (regina) as well as her position as wife (coniux). Most importantly, Hildegard is presented as an active collaborator with her husband, and therefore as a political agent in this transaction. But the significance of her presence is better understood in relation to the object of the charter. As Janet Nelson has noted, this grant represents the displacement of the last Lombard queen, Ansa, whose husband Desiderius had been deposed by Charles. ${ }^{25}$ After the conquest of Italy, Charles tried to bring the Lombard religious institutions under his control. ${ }^{26}$ Sirmione was one of these institutions: Ansa had founded a little monastery there, which is explicitly mentioned in Charles' diploma ("monasteriolo illo [...] quem Ansa novo opere construxit"). Interestingly, in the document Ansa is pre-

22 Cf. Janet Nelson, Charles the Bald, London 1992, 179.

23 Die Urkunde Karls des Großen, n. 81, in: Engelbert Mühlbacher ed., Die Urkunden Pippins, Karlmanns und Karls des Großen, MGH DD Kar. I, Hannover 1906.

24 Cf. Herwig Wolfram, Intitulatio I. Lateinische Königs- und Fürstentitel bis zum Ende des 8. Jahrhunderts, Graz 1967, 217-221; Roger Collins, Charlemagne, Basingstoke 1998, 61-62.

25 Cf. Janet Nelson, The Settings of the Gift in the Reign of Charlemagne, in: Wendy Davies and Paul Fouracre eds., The Languages of Gift in the Early Middle Ages, Cambridge 2010, 116-148, 121-126.

26 Cf. Paolo Cammarosano, Nobili e re. L'Italia politica dell'alto medioevo, Bari 1998, 103-105. 
sented without any attributes to identify her; ${ }^{27}$ this is no surprise considering her background. During the reign of her husband, she had been a very active monastic patron and landowner in northwestern Italy, where she had extensive landed resources. Her main monastic foundation, San Salvatore in Brescia, was located on the land she had received from her natal family. ${ }^{28}$ The nunnery had substantial wealth; in 765 it was also assigned the control of Sirmione. ${ }^{29}$ Furthermore, although Desiderius and Ansa had been imprisoned in France, their children still represented a threat: Adelchis, the heir to the throne, was still alive, as were their three daughters, who all held influential positions. ${ }^{30}$ One of them, Anselberga, was the abbess of San Salvatore in Brescia. Finally, Ansa was also Charles' former mother-in-law: in 770, the Frankish king had married one of her daughters - possibly called Gerberga - and repudiated her a year later. ${ }^{31}$

Thus there were several reasons why Charles was wary of Ansa's legacy in Italy, which explains his intention to deprive the former queen of her familial, political and institutional attributes. But if Charles had wanted to anonymise Ansa, why mention her at all? In this document she appears as a symbol of the political transition which had recently taken place. Ansa is mentioned in several royal charters issued by her husband Desiderius and her son Adelchis regarding the endowment of her main monastic foundation, San Salvatore. All these documents present Ansa with her title as queen and emphasise her pivotal role in the royal family's relationship to the convent. ${ }^{32}$ Hildegard therefore appears at Charles' side as a contraposition to Ansa's fading influence. Not just her appearance in the document per se is significant but also the language through which her presence is described. ${ }^{33}$ Charles was the new king of the Lombards, therefore the document celebrates the new queen (regina). The active part which was assigned to Hildegard in relation to a religious house founded by her Lombard predecessor stresses this change in power and shows how keen Charles was to underline it also through his

27 As already noted by Nelson, Settings, see note 25, 126.

28 Cf. Suzanne Wemple, S. Salvatore/S. Giulia: A Case Study in the Endowment and Patronage of a Major Female Monastery in Northern Italy, in: Julius Kirshner and Suzanne Wemple eds., Women of the Medieval World, Oxford 1985, 85-102; Cristina La Rocca, Les cadeaux nuptiaux de la famille royale en Italie, in: François Bougard, Laurent Feller and Régine Le Jan eds., Dots et douaires dans le Haut Moyen Age, Roma 2002, 499-526, 505-506.

29 Luigi Schiaparelli ed., Codice Diplomatico Longobardo, II, n. 188, in: Fonti per la Storia d'Italia 63 (Roma 1933).

30 Cf. Janet Nelson, Making a Difference in Eighth-Century Politics: the Daughters of Desiderius, in: Alexander Murray ed., After Rome's Fall. Narrators and Sources of Early Medieval History, Toronto 1998, 171-190.

3I Nelson, Difference, see note 30, 178-184.

32 On Ansa's titles and attributes cf. La Rocca, Monachesimo, see note 21, 124-128. On the patronage of San Salvatore cf. Gian Pietro Brogiolo, Desiderio e Ansa a Brescia: dalla fondazione del monastero al mito, in: Carlo Bertelli and Gian Pietro Brogiolo eds., Il futuro dei Longobardi. L'Italia e la costruzione dell'Europa di Carlo Magno, Genève/Milano 2000, 143-155.

33 Cf. Nelson, Settings, see note 25, 126, stressing the significance of Hildegard as a member of the royal family. 
wife's intitulatio. The roles that the two women played in this charter advertise a new state of affairs: the former influential queen of the Lombards was marginalised and replaced by Charlemagne's wife. The role reversal between Hildegard and Ansa is stressed not only by the content but also the language of Charles' diploma. Therefore, this diploma shows that the meaning and significance of queenly titles, such as regina, can be better understood in relation to the context of the document, as well as of all the actors involved. Titles ascribed to royal women can help to reveal models of female agency as well as the objectives that were assigned to them.

\section{Ermengard and Carolingian Family Politics}

Like most medieval sources, charters were composed and mainly read by men: women's involvement in the process was rather limited. In the case of Hildegard, the lack of further evidence makes it difficult to establish whether she actively took part in Charles' decisions and whether her representation in the document is related to her involvement in the administration of the monasteries. ${ }^{34}$ Nonetheless, in some cases diplomas offer us an insight into women's own agency and the impact of their decisions on the way in which they were portrayed in charters. In other words, through their choices and resources, royal women could contribute to their own representation. The case of Ermengard, the ambitious woman mentioned at the beginning of this article, sheds light on the opportunities which not only queens, but also other women of the royal family, enjoyed. Thanks to her landed resources and her connections, which stretched from Italy to France, Ermengard was a key political player in the last quarter of the ninth century. This is illuminated in the diplomas through which she obtained gifts and confirmations by the rulers of her family. These documents show how timely and effective Ermengard's requests for herself and her family were. They also represented her as a virtuous mother and family woman. These portrayals were partially the result of Ermengard's own concerns, as she indeed fought for the interests of her kin. At the same time, they expressed the agenda of the rulers who issued the charters. Their narratives are framed around the protection of a fragile kinswoman, while in effect the rulers obtained the support of a significant political actor.

In February 875, Ermengard, at the time still unmarried, received a donation from her great-uncle Louis the German, King of East Francia. ${ }^{35}$ Ermengard's father, the Emperor and King of Italy Louis II, was still alive, but he did not have any male children. In the early 870 s, negotiations had taken place between Louis and his relatives to decide who should succeed him. The two candidates were Louis's paternal uncles, Charles

34 On Hildegard's career cf. also Nelson, Women, see note 8, 234.

35 Die Urkunden Ludwigs des Deutschen, n. 157, in: Paul Kehr ed., Die Urkunden Ludwigs des Deutschen, Karlmanns und Ludwigs des Jüngeren, MGH DD Reg. Germ. Kar. I, Berlin 1932-34. 
the Bald and Louis the German. Louis II's preference was set towards Louis the German and his sons. ${ }^{36}$ The donation for Ermengard has to be read precisely in this context. The charter tells us that Ermengard requested Louis the German to confirm properties in Italy given to her by her father. ${ }^{37}$ However, the East Frankish king had de facto no jurisdiction over the properties mentioned in the charter, which were fiscal estates belonging to the domain of the king of Italy. ${ }^{38}$ It is possible that this charter was requested by the Italian court to protect the princess' rights in the event of her father's death. In fact, Louis II died only a few months later, in August 875. Most importantly, Ermengard's request was employed to record a political agreement between Louis II and Louis the German. By allowing his uncle to protect his daughter's Italian estates, Louis II publicly performed his agreement to leave his legacy to him. In this case a royal woman was employed as an ambassador for a significant political event. By formally entrusting his daughter's rights to his uncle, the charter proclaimed the familial connection between the two rulers. As an unmarried young woman, Ermengard effectively embodied this message. She was in need of protection, which her male relatives could offer. On the other hand, her great-uncle Louis the German was eager to present himself as the ideal candidate to this role. The charter presented the matter as a family affair, while it in fact advertised a political alliance, intending to exclude other members of the family with designs on the Italian crown. For this reason, Ermengard spoke in her capacity of a kinswoman: she obtained the properties from her father as a royal daughter and asked for confirmation by her great-uncle as a beloved niece.

It is likely that at this stage Ermengard had very little say in the transaction. However, this document also shows Ermengard's own agenda emerging some years later. The original version provided that the properties confirmed to Ermengard by Louis the German were to be returned to him - or rather to his descendants - after her death. This passage was altered a few years later, stating that the holdings should remain in the hands of Ermengard's descendants: the expression "suae proprietate", which refers to Louis the German, was changed into the phrase "to her daughter" ("suae filiae"), thus indicating that the properties had to be passed on to Ermengard's female offspring. ${ }^{39}$

36 Cf. Eric Goldberg, Struggle for Empire: Kingship and Conflict under Louis the German, 817-876, Ithaca 2006, 324-326; Simon MacLean, "After his death a great tribulation came to Italy ..." Dynastic Politics and Aristocratic Factions after the Death of Louis II, c. 870-c. 890, in: Millennium. Jahrbuch zu Kultur und Geschichte des ersten Jahrtausends n. Chr., 4 (2007), 239-60, 244-248.

37 Die Urkunden Ludwigs des Deutschen, n. 157, see note 35: “[...] qualiter dilecta nepta nostra Hirmingarda deprecata est celsitudinem nostram, ut ob mercedis nostrae augmentum quasdam res proprietatis nostrae consistentes in Italia ei in proprium concedissemus."

38 The properties listed in the document were: Murgula (Bergamo), Almenno (Bergamo), Cortemaggiore (Piacenza), Aucia (Piacenza) and a monastery in Pavia, cf. Paul Darmstädter, Das Reichsgut in der Lombardei und Piemont (568-1250), Strassburg 1895, 106-109, 144-145.

On this alteration cf. Die Urkunden Ludwigs des Deutschen, see note 35, 220. 
This alteration obviously took place after Ermengard was married and had children and offers a glimpse into the ability of royal women to protect their resources. Ermengard seems to have been particularly skilled in advocating the interests of her family group. She married Boso in 877 and, as mentioned above, was an active party in her husband's short lived political venture. ${ }^{40}$ Boso died in 887 leaving her a widow with a five-year-old son and at least one daughter, whose interests needed to be protected. In the same year, Emperor Charles the Fat (881-888), the son of Louis the German, confirmed the properties that Ermengard had received from her father. ${ }^{41}$ This donation was issued after a period of conflict between Ermengard's group and Charles. ${ }^{42}$ Ermengard's mother Angelberga, the powerful dowager with extensive landed resources in Italy, had been in a conflicting relationship with Charles, who had sent her into exile for a few years. ${ }^{43}$ However, now that her husband was dead, Ermengard needed external support. Charles, on the other hand, could benefit from protecting Ermengard's extensive resources in Italy and Provence. ${ }^{44}$ Similar to the diploma issued in 875 , the 887 charter is not only about land and wealth but records a political agreement. Ermengard wanted to secure her own and her kin's interests: as such the charter underlines her family role. ${ }^{45}$ In this document we see a mother asking for her children and also a ruler who is interested in acting as her protector because of her power and connections. This is stressed in the arenga, the formal introduction of the charter: it states that a ruler has a duty to take care of the members of his family (domesticorum nostrum), hence stressing the relationships which bound together the people involved in the transaction. This donation was thus also a way of declaring an appeasement within the turbulent Carolingian family.

Two years later, in 889, Ermengard appeared again in a royal diploma, this time acting as both petitioner and intercessor. ${ }^{46}$ In late 887, Arnulf of Carinthia had deposed his uncle Charles the Fat and became king of East Francia. ${ }^{47}$ In June 889, the new king

\footnotetext{
40 Cf. Bougard, Ermengarda, see note 2.

4I Die Urkunden Karls III., n. 165, ed. by Paul Kehr, MGH DD Reg. Germ. Kar. II, Berlin 1936-37.

42 Cf. Simon MacLean, Kingship and Politics in the Late Ninth Century: Charles the Fat and the End of the Carolingian Empire, Cambridge 2003, 165-167.

43 Cf. Roberta Cimino, Angelberga, il monastero di San Sisto di Piacenza e il corso del fiume Po, in: Tiziana Lazzari ed., Il patrimonio delle regine: beni del fisco e politica regia tra IX e X secolo, Reti Medievali-Rivista, 13, 2 (2012), at: http://rivista.retimedievali.it, 141-162, 154.

44 The territorial extent of Ermengard's wealth is revealed in this passage that refers to her properties: "ex diversis partibus tam in Italia quam Burgundia vel Frantia” (Die Urkunden Karls III., n. 165, see note 41).

45 Die Urkunden Karls III., n. 165, see note 41: "Cuius petitionem benigno suscipientes affectu iussimus hoc nostrae auctoritatis praeceptum fieri, per quod illi filioque suo Hludouuico, nepoti scilicet nostro, et sororibus eius integerrime restituimus et confirmamus universas proprietates et familias [...]."

46 Die Urkunden Arnolfs, n. 49, ed. by Paul Kehr, MGH DD Reg. Germ. Kar. III, Berlin 1940.

47 Cf. MacLean, Kingship, see note 42, 191-198.
} 
confirmed Ermengard's and her mother's properties in Italy, also stating that Ermengard's wealth should be left to her daughter. ${ }^{48}$ As a daughter and a mother, Ermengard is the advocate of a multigenerational group of women appealing to a ruler who could help them. ${ }^{49}$ At the same time, the document portrays Arnulf as someone who respects the disposition of his ancestors and the rights and interests of the women of his family, hence advertising his generosity. ${ }^{50}$ However, Arnulf's willingness to protect Ermengard was not without vested interest. In 889, Italy was in the hands of a local aristocrat, Guy of Spoleto, who had managed to be elected king by taking advantage of the weakness of the Carolingians in Italy. ${ }^{51}$ Arnulf's goal was to obtain control of Italy and ultimately to become emperor. Like Louis the German in 875, the Italian properties he confirmed to Ermengard did not belong to his sphere of influence, even though the charter stressed his authority there. ${ }^{52}$ Therefore this diploma was an opportunity for Arnulf to proclaim his influence over Italy. The landed resources and connections to monasteries that both Ermengard and her mother had in that area offered him the opportunity to do so. The charter emphasises the importance of family bonds: the confirmation of Ermengard's wealth is presented as the result of Arnulf's generosity towards a group of vulnerable women, thus portraying him as a virtuous ruler. At the same time, it explicitly stresses his claims on Italy.

Ermengard supported the election of her son Louis as king of Provence and remained at his side until her death in $896 .{ }^{53}$ The charters discussed here show her influence and offer an insight in the way women could be employed to describe, promote and perform political alliances. Female voices could be a vehicle of political communication. Royal women represented the contacts between the various branches of the Carolingian family, and the gendered rhetoric of their weakness and vulnerability could also be an excellent way of advertising a ruler's kindness and piety. In some cases, women were also able to take advantage of the role that was assigned to them. Ermen-

48 Die Urkunden Arnolfs, n. 49, see note 46: "Similiter autem pręlibatę filiae suę post illius discessum haec omnia potestativę tenenda et sicut ei libuerit disponenda pro consanguinitatis nodo per hoc idem conscriptum concedere decrevimus firmissimę iubentes [...]."

49 Die Urkunden Arnolfs, n. 49, see note 46: "[...] cognatam nostram nomine Irmingardam ad nostri culminis praesentiam direxerat supplicans."

50 Die Urkunden Arnolfs, n. 49, see note 46: "At nos pro amore Christi eiusque congruę supplicatione prędicteque neptis nostrae dilectione libenter illi assensum prebentes decrevimus ita fieri."

5I On Arnulf's expeditions to Italy and his relationship with Italian magnates cf. Carl Hammer, Crowding the King: Rebellion and Political Violence in Late-Carolingian Bavaria and Italy, in: Studi Medievali, 3rd series, 48 (2007), 493-541, esp. 511-517.

52 Die Urkunden Arnolfs, n. 49, see note 46: "Concessimus itaque ei more antecessorum nostrorum subnotata loca, quae in iam dicto regno sita esse dinoscuntur, [...] de iure et dominatione nostra in ius et dominium donamus et tradimus[...]."

53 Cf. Pierre Ganivet, La consolation de l'Empire. Louis III de Provence, dit "l'Aveugle", ou les ambitions d'un prince, in: Hortus Artium Medievalium, 8 (2002): Carolingian Europe, ed. by Miljenko Jurkovic and Ante Milosevic, 179-191, 182-184. 
gard is an excellent example of this: she requested and obtained donations and confirmations from rulers because she needed their protection, but also because they needed her collaboration. Her presence in charters is always very timely: it coincides with moments when a new ruler needed to establish himself or to gain a stronger hold of some key territories. The way she was presented in diplomas was useful to both parties: to Ermengard, who was portrayed as a mother and a daughter trying to safeguard her own family, and to the rulers who protected her through the rhetoric of familial solidarity.

\section{Conclusion}

The language used to describe Carolingian women in diplomas offers an insight into the multiple functions that women held in royal politics. Women were allowed to carry out the same tasks as men: they requested gifts and confirmations for themselves, interceded for friends, family and religious institutions, and even made autonomous decisions. The language of diplomas emphasises that they fulfilled these roles thanks to their personal relationship with the king but also to the opportunities offered by their gendered role: the spiritual care of the family and the administration of the household were tasks typically reserved for women. Through these tasks they gained influence and established bonds with individuals and religious institutions. The language employed in diplomas to describe these functions is to be read in relation to the textual and political context in which it was used. Only in this way the terminology can reveal significant information on the deeper purpose of the document. The examples mentioned above illuminate the relevance of specific terms used for royal women. The diplomas of Charles the Bald stress Ermentrud's capacity as an informer and manager of landed resources thanks to her role as a monastic patron and rectrix. Hildegard's intitulatio and her involvement in the grant of a Lombard monastery to St Martin of Tours cast light on Charles' concerns regarding the influence of the former queen Ansa and her kin. In diplomas issued by Carolingian rulers between 875 and 889, Ermengard is described by a terminology that underlines the family bonds of all actors concerned, when she speaks as a beloved niece, daughter and mother. The emphasis on her family role is relevant to the goals of each charter and the political situation in which they were issued. It aims to display a harmonic family picture of a dynasty troubled by conflict and competition.

The nature of formulaic and complex texts such as diplomas poses a challenge in attempting to deconstruct their language, particularly with regard to women. Nonetheless, analysing them in relation to the political situation in which they were produced allows us to read stories of female activism. The way in which women spoke for themselves or on account of others was framed by the authors of the charters, but, at the same time, their own goals can also emerge in those texts. This was the case of Ermengard, whose political and familial agenda is likely to have influenced the way in which 
she was portrayed in the charters she requested. Carolingian royal women enjoyed a wide array of possibilities and had many opportunities to be involved in the political reality in which they lived. The crucial significance of their speaking abilities lay in the unique flexibility of their role. 